\title{
编者按 核能领域关键力学问题专题 \\ Special topic: key mechanics problems in nuclear energy
}

\section{核能领域关键力学问题专题 编者按}

在全球能源紧缺的背景下, 核能作为一种清洁、可持续、能大规模应用的能源, 势必成为未 来几十年最有发展前景的新能源之一。我国《核电中长期发展规划(2011-2020 年)》和《能源发 展战略行动计划(2014-2020 年)》明确指出要安全高效发展核电, 提高核电在能源供应中的比重。 另一方面, 我国核电站大多分布在粤港澳大湾区等沿海经济发达、人口密集区, 一旦发生类似 2011 年日本福岛核事故, 将对我国能源战略、社会安全和核能 “走出去” 造成难以弥补的影响。 因此, 安全高效发展核电对于我国能源安全和经济安全具有重要战略意义。

我国在运和在建核电站以压水反应堆为主, 以核裂变能和水冷却剂为主要特征。核结构和材 料在高温、辐照、腐蚀环境下的力学性能及其老化决定着关键核电装备和构件的性能和服役寿命。 核反应堆一二回路的流动传热特性直接影响反应堆的换热效率。因此, 核反应堆系统的关键力学 问题研究对于核电安全性和经济性具有举足轻重的作用。其中, 最关键是对核反应堆系统相关力 学特性进行定量可靠预测, 从而实现核电厂更合理的生命周期管理（设计、建造、运行、维修和 退役)。核反应堆具有多物理和多时空尺度的复杂性。多物理是指力学、材料、热工水力、核物 理、核化学等多领域交叉; 多时空尺度体现在时间上从数十年服役周期到秒级以下的核物理反应, 空间上从几十米的安全壳到数毫米的燃料芯块、纳米级的材料辐照缺陷, 带来了理论和技术上的 极大挑战。

目前核能领域仍存在不少尚未解决的关键问题, 力学在其中扮演举足轻重的角色, 如: 压力 容器辐照脆化的断裂㓞性定量预测理论, 核燃料芯块的考虑微结构损伤演化的本构模型, 核燃料 包壳的力-热-中子全耦合预测理论, 堆内构件及材料的应力腐蚀模型, 堆内外构件的强度评估准 则, 堆芯在稳态、瞬态和事故工况下的流动传热、堆芯熔融等的复杂流固耦合问题, 多物理全尺 度模拟和降阶计算方法, 模拟核电环境材料力学性能的等效加速测试方法等。

为了展示我国近些年在核能领域尤其是反应堆结构、材料、流动传热等相关力学问题的部分 研究成果, 特别组织了本次核能领域关键力学问题专题, 由 9 篇综述论文和研究论文组成, 涉及 核燃料、核材料、核结构、热工水力等方面。专题着重回顾了压水堆材料与结构中的关键力学问 题及发展趋势; 介绍了核电运行及事故颗粒物运动沉积分析方法; 介绍了超临界水堆辐照考验回 路多尺度热工水力学分析方法和成果; 介绍了参数化高保真模型的快速求解计算方法; 介绍了单 片式燃料元件辐照热-力耦合行为的理论研究; 介绍了 $\mathrm{UO}_{2}$ 核燃料中气泡演化的相场模型与分析; 介绍了典型核合金的基于晶体塑性模型的集成计算材料模拟研究成果; 介绍了典型核能装置用石 墨构件的应力分析方法; 介绍了核燃料循环的硼硅酸盐玻璃离子辐照效应研究。希望通过本期专 题的出版, 凝练核能领域的关键力学问题, 吸引更多学术界和工程界科研人员投身到核能力学问 题的研究中, 为解决制约核能安全与可持续发展做出重要的贡献。 